\title{
Limnological study of Dokan, Derbendikhan and Duhok lakes, Kurdistan region of Iraq
}

\author{
Janan Jabbar Toma
}

Department of Environmental Sciences, College of Sciences, University of Salahaddin, Hawler, Iraq; janan toma@yahoo.com

Received 23 March 2012; revised 3 June 2012; accepted 22 July 2012

\begin{abstract}
The present study deals with the assessment of physico-chemical characteristics of Dokan, Derbendikhan and Duhok lakes. The physico-chemical characteristics of these lakes have been studied and analyzed for a year, during JanuaryApril-July and October 2009. Seasonal variations of two sampling sites of the lakes have been observed. Various parameters including air temperature, water temperature, electrical conductivity, TDS, pH, total alkalinity, total hardness, dissolved oxygen, calcium, magnesium, sodium, potassium, sulfate, chloride, nitrite and phosphate have been analyzed. The study has revealed that there are significant seasonal variations in some physico-chemical parameters and as a whole most of the parameters are different in the three lakes.
\end{abstract}

Keywords: Limnological Study; Dokan;

Derbendikhan; Duhok; Lake

\section{INTRODUCTION}

Water is an indispensable natural resource on earth. The existence of life including human beings depends on it. It is an enormous resource on the earth amounting to about 13, 481, 96,000 $\mathrm{Km}^{3}$. Due to its unique properties, water is also of multiple uses for living organisms [1]. Human beings depend on water for almost every developmental activity. It is used for drinking, irrigation, washing, and Industrial purposes. Although water is very abundant on this earth, yet it is very precious. Out of the total water reserves of the world, about $97 \%$ is salty water and only 3\% is fresh water. Even this small fraction of fresh water is not available to us as most of it is locked up in polar ice caps and just $1 \%$ is readily available to us in the form of ground water and surface water [2]. The surface water is one of the most important resources for human survival. Unfortunately, many countries and regions face problems of water pollution and degradation.
Anthropogenic influences and natural processes can degrade surface waters and impair their use for drinking, agriculture, recreation and other purposes [3,4]. Here comes the importance of reservoirs which are man-made lakes constructed by impounding rivers. This impoundment is mainly used for irrigation, hydroelectric power generation, water supply, navigational and flood control purposes [5]. However, the ecology of reservoirs is radically different from that of the rivers because of the fact that dams alter river hydrology both up and down. The obstruction of the river flow with the consequent inundation triggers off a sudden transformation of lotic environment into a lacustrine one. The physico-chemical parameters are very important in the study of any environment, especially aquatic environment. Besides, limnology plays an important role in decision making processes for problems like dam construction, pollution control, fish and aquaculture practices [6]. It deals with the physical, chemical and biological characteristics in relation to all other hydrological properties. Any characteristic of water that affects the survival, reproduction, growth and production of aquaculture species, influences management decisions, causes environmental impacts or reduces product quality and safety can be considered a water quality variable [7]. Limnology and water quality provide current information about the concentration of various solutes at a given place and time. Water quality parameters in specific provide the basis for judging the suitability of water for its designated uses and to improve existing conditions. For the sake of optimum development and management for the beneficial uses, current information is needed which is provided by water quality programmes [8]. Unequal distribution of water on the surface of the earth and fast declining availability of useable fresh water are the major concerns in terms of water quantity and quality [8]. The availability of water in Iraq shows a steady relation with spatial and temporal variability. The increase in population and expansion of economic activities undoubtedly leads to increasing demand of water use for various purposes. On the other hand, water resources in Iraq, especially in the last two decades, have suffered from remarkable stress in terms 
of water quantity due to different reasons such as the dams built on Tigris and Euphrates in the riparian countries, the global climatic changes, the local severe decrease of the annual precipitation rates and the improper planning of water uses inside Iraq $[9,10]$. In addition to that, water quality is certainly affected by the quantity and quality of supplies coming from different sources. Therefore, overall national planning and resource management in respect of water with emphasis on allocation of priorities among the different uses is necessary. It is not surprising that, due to the above factors, studying water quality is so much important to be carried out in order to keep our awareness and understanding of our environment. The present study is designed to monitor seasonal variation in water quality parameter in order to investigate the limiting factors, which could adversely affect the plants and animals, including fish production in these important lakes, and compare the variations among these lakes understudied with respect to physical and chemical characteristics.

\section{MATERIAL AND METHODS}

The water samples were collected for physico-chemical analysis from two sites at regular intervals of one year seasonally from January-April-July and October 2009. The air temperature, water temperature, dissolved oxygen; electrical conductivity and $\mathrm{pH}$ were estimated on the spot at the time of sampling while other parameters were estimated in the laboratory. Standard methods as prescribed by [11] were followed for examination of various physical and chemical parameters of water.

\section{DESCRIPTION OF THE STUDY SITES}

Two sites have been studied in Dokan lake considered the largest lake in the Iraqi Kurdistan region, and which lies in the northwestern part of Sulaimamiyah, about 76 $\mathrm{km}$ from the city center [12]. To study the physical and chemical variables, one site was selected from the right side of the lake, while the second site was selected from the left side. Both the physical and chemical factors showed seasonal variations over a period of 4 seasons (10-1-2009, 10-4-2009, 10-7-2009 and 10-10-2009) respectively (Figure 1). The lake has a full-pool operating altitude of $515 \mathrm{~m}$ above mean sea level and its boundaries extend between latitude of $34^{\circ} 17^{\prime} \mathrm{N}-36^{\circ} 33^{\prime} \mathrm{N}$ and a longitude of $43^{\circ} 17^{\prime} \mathrm{E}-46^{\circ} 24^{\prime} \mathrm{E}$. It was constructed in (1954-1959) by the construction of Damez-Bullot Dam (a French company) on the lesser Zab River near Dokan gorge to prevent flooding, irrigation, electric generation, fishery and recreation [12]. The major outlet establishes the Lesser Zab River with its Mahor tributaries (Karfin and Shahrawan) and other waters in addition to rainfall and snow fall/snow melt water [13]. The volume of the lake is 6.8 billion cubic meters with a surface area of about $270 \mathrm{~km}^{2}$ and $48 \mathrm{~km}^{2}$ at high and low level period, respectively. The drainage area is covering about 11,690 $\mathrm{km}^{2}$ of which $1080 \mathrm{~km}^{2}$ are located within Qala-Diza and Raniya plains [14]. The geology of the area consists of marl, calcareous and limestone [15]. The collection decision of [15] and [16] regarding the climate of the studied area is a dry-summer approach of Irano-Turanian type characterized by the occurrences of three seasons: a cold winter, mild growing period of spring and hot-dry summer.

Two sites have also been studied in Derbendikhan lake which lies on the southeast of Sulaimamiyah, to study the physical and chemical variables. One was selected from the right side of the lake, while the second site was selected from it's the left side. Both the physical and chemical variables were carried out seasonally over a period of 4 seasons (15-1-2009, 15-4-2009, 15-7-2009 and 15-10-2009) respectively (Figure 2). The lake has a full-pool operating altitude of about $485 \mathrm{~m}$ above sea level [17]. The area of this lake is about $114.30 \mathrm{~K}^{2}$ with the maximum depth of $75 \mathrm{~m}$ [16].The estimated volume of the Derbendikhan lake ranges from $1.3-1.4 \mathrm{~km}^{3}$ [17]. Its boundaries extend from (latitude $35^{\circ} 6^{\prime} \mathrm{N}-35^{\circ} \mathrm{N}$ and longitudinal $45^{\circ} 41^{\prime} \mathrm{E}-20^{\circ} \mathrm{E}$ ). Thus, it is considered the second largest lake in the Iraqi Kurdistan region. Consequently Derbendikhan can be classified as a limnetic water body which is warm and monomictic and with only one

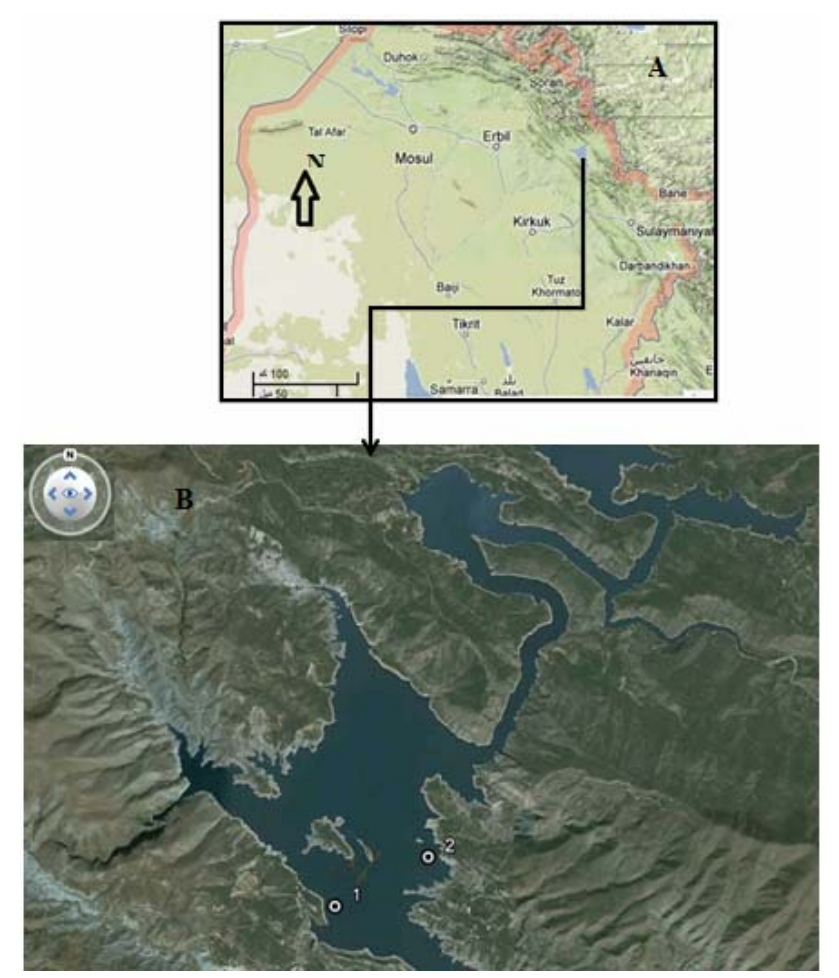

Figure 1. A-Map of Northern Iraq show Dokan Lake; BMap of Dokan Lake shows the location of studied area. 


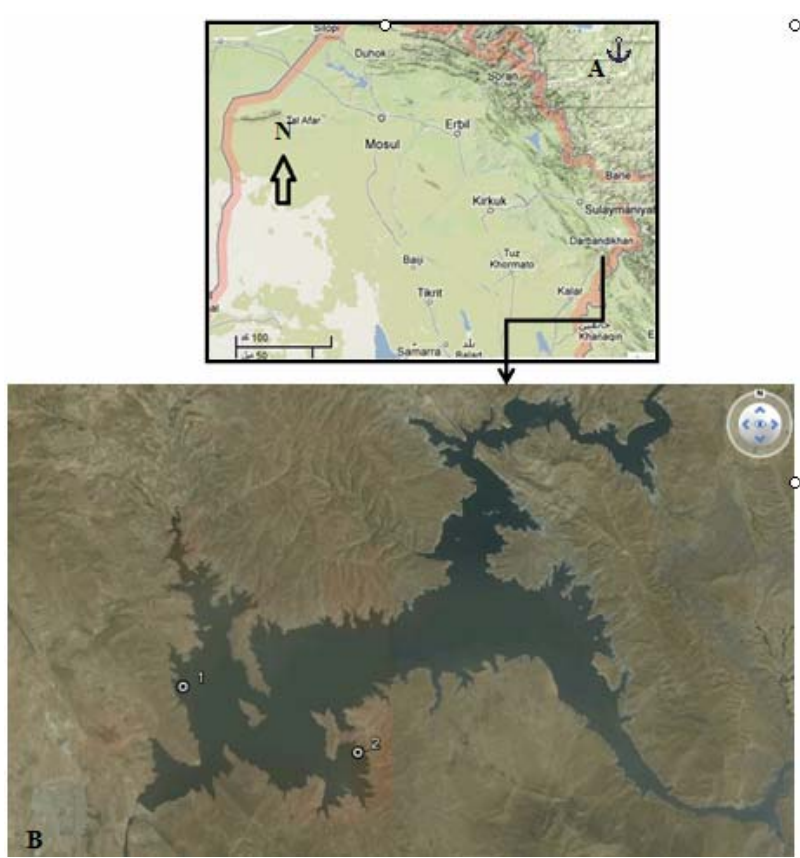

Figure 2. A-Map of Northern Iraq show Darbendikhan Lake; B-Map of Darbendikhan Lake shows the location of studied area.

circulation period in winter and water temperature never falls below $4^{\circ} \mathrm{C}$ [18]. The geology of the area consists of sedimentary rocks of marine origin [17]. The collection decision of [19] regarding the climate of the studied area is a dry-summer approach of Irano-Turanian type characterized by the occurrences of three seasons: a cold winter, mild growing period of spring and hot-dry summer.

Furthermore, two other sites have been studied in Duhok lake which lies in the north part of Duhok, about 2 $\mathrm{Km}$ from the city center, of altitude $36^{\circ} 50^{\prime} 49^{\prime \prime}$ and longitudinal $43^{\circ} 00^{\prime} 33^{\prime \prime}$. To study the physical and chemical variables, one was selected from the right side of the lake, while the second site was selected from its left side. The study of the physical and chemical factors were carried out seasonally over a period of 4 seasons (20-1-2009, 204-2009, 20-7-2009 and 20-10-2009) respectively (Figure 3). Duhok dam was established in 1987 on Duhok river. Impounding a surface area of around 256 hectares has made it the third largest lake in southern Kurdistan of Iraq after Dokan and Derbendikhan lakes with surface areas of 27,000 and 1200 hectares respectively. It is an artificial lake and its water mainly comes from rain, snowmelt and the main tributaries of Sunder and Gurmava which on their joining make up Duhok river. The geology of the area consists of clay marl, dolomite, poly clay limestone and sandstone [20]. The climate of the studied area is a dry-summer approach of Irano-Turanian type characterized by the occurrences of three seasons: a cold winter, mild growing period of spring and hot-dry summer $[16,19]$.

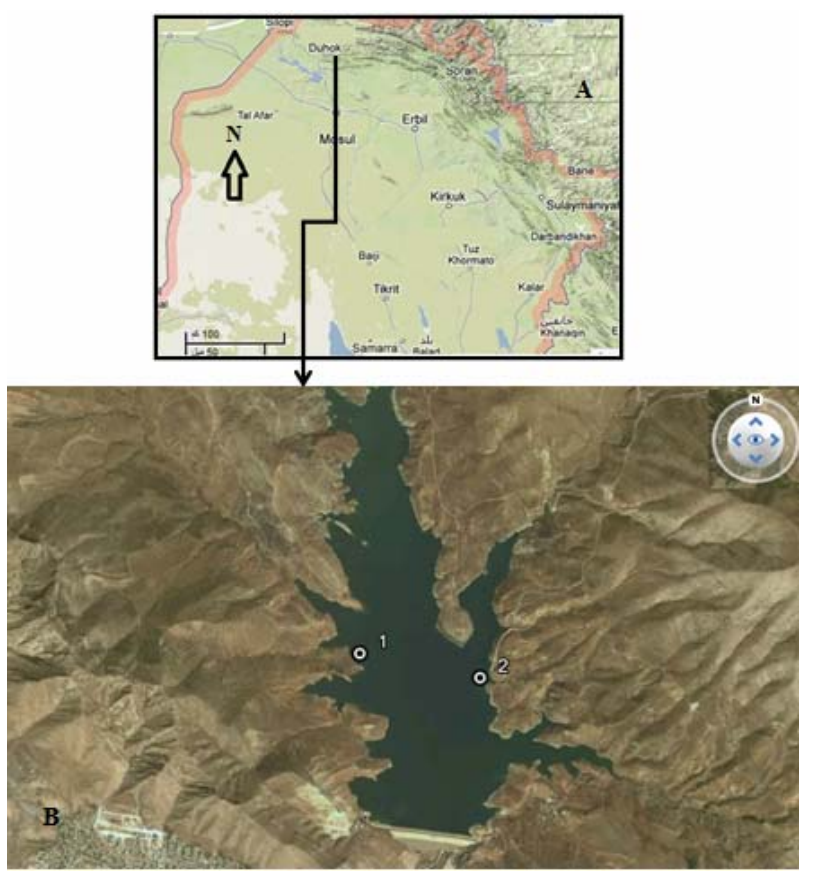

Figure 3. A-Map of Northern Iraq show Duhok Lake; BMap of Duhok Lake shows the location of studied area.

\section{RESULTS AND DISCUSSIONS}

Variations of physico-chemical characteristics of Dokan, Derbandikhan and Duhok lakes during winter, spring, summer and autumn 2009 are shown in Tables 1-4).

Air temperature in the present study was recorded a maximum value in July of $\left(35^{\circ} \mathrm{C}\right)$ in Derbendikhan lake while a minimum value measured in January of $\left(8^{\circ} \mathrm{C}\right)$ in Duhok Lake. Photoperiod is shorter in winter than summer; it is directly related to temperature [21]. Both photoperiod and temperature are maximum in July.

The water temperature and air temperature are found to go more or less hand in hand [21]. The surface water temperature of the studied area is found to vary from $6^{\circ} \mathrm{C}$ in Duhok Lake to $31^{\circ} \mathrm{C}$ in Derbendikhan Lake. On the other hand, summer temperature (July) is always above winter temperature (January). The decrease or increase in water temperature of the lakes depends mainly on the climatic conditions, sampling times, the number of sunshine hours and is also affected by specific characteristics of water environment such as turbidity, wind force, plant cover and humidity [22]. Similar conclusions are made by $[13,23,24]$.

As far as the $\mathrm{pH}$ is concerned, it varies from 7.2 in Dokan Lake to 8.4 in Derbendikhan Lake, indicating that the water samples are almost alkaline in nature. The $\mathrm{pH}$ is an important factor that determines the suitability of water for various purposes [25]. The observed values show a relative agreement with $\mathrm{pH}$ values of surface water which lie within the range of 6.5 to 8.5 [26]. However, the values come also in accordance with the known values 
Table 1. Physico-chemical variables that are recorded in Dokan Lake during the study period.

\begin{tabular}{|c|c|c|c|c|c|c|c|c|}
\hline Sites & & Sit & e 1 & & & Site & & \\
\hline Variable sample date & $\begin{array}{l}\stackrel{8}{\circ} \\
\frac{1}{1} \\
.\end{array}$ & $\begin{array}{l}\stackrel{8}{0} \\
\text { ஸे } \\
\text { +े } \\
\text { o }\end{array}$ & $\begin{array}{l}\stackrel{0}{0} \\
\stackrel{N}{1} \\
\frac{1}{0} \\
\stackrel{0}{1}\end{array}$ & 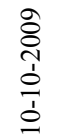 & $\frac{\stackrel{8}{\circ}}{\stackrel{1}{1}}$ & 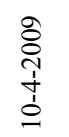 & 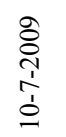 & $\begin{array}{l}\stackrel{8}{0} \\
\stackrel{\leftrightarrow}{1} \\
0 \\
\vdots \\
0\end{array}$ \\
\hline Air temp. ${ }^{\circ} \mathrm{C}$ & 9 & 22 & 32 & 25 & 10 & 21 & 33 & 24 \\
\hline Water temp. ${ }^{\circ} \mathrm{C}$ & 8 & 18 & 28 & 22 & 9 & 18 & 29 & 22 \\
\hline $\mathrm{pH}$ & 7.2 & 7.6 & 7.7 & 8.1 & 7.3 & 7.5 & 8.0 & 7.8 \\
\hline $\mathrm{EC} \mu \mathrm{s} / \mathrm{cm}$ & 205 & 250 & 385 & 400 & 240 & 265 & 390 & 410 \\
\hline $\mathrm{TDS} \mathrm{mg} / \mathrm{L}$ & 132 & 152 & 250 & 235 & 155 & 167 & 247 & 250 \\
\hline Alkalinity $\mathrm{mg} \mathrm{CaCO} / \mathrm{L}$ & 175 & 180 & 250 & 220 & 180 & 190 & 240 & 230 \\
\hline Hardness $\mathrm{mg} \mathrm{CaCO}_{3} / \mathrm{L}$ & 150 & 145 & 185 & 180 & 165 & 158 & 195 & 190 \\
\hline Dissolved Oxygen mg/L & 9.5 & 6.5 & 5.0 & 6.5 & 9.0 & 6.3 & 5.0 & 6.2 \\
\hline $\mathrm{Ca}^{+2} \mathrm{Mg} / \mathrm{L}$ & 40 & 30 & 47 & 45 & 42 & 33 & 57 & 50 \\
\hline $\mathrm{Mg}^{+2} \mathrm{mg} / \mathrm{L}$ & 15 & 12 & 20 & 16 & 16 & 13 & 21 & 18 \\
\hline $\mathrm{Na}^{+} \mathrm{mg} / \mathrm{L}$ & 3.8 & 3.5 & 5.6 & 5.0 & 4.0 & 4.2 & 7.5 & 7.0 \\
\hline $\mathrm{K}^{+1} \mathrm{mg} / \mathrm{L}$ & 1.1 & 1.0 & 2.0 & 1.9 & 1.3 & 1.2 & 2.1 & 2.0 \\
\hline$\left(\mathrm{SO}_{4}\right)^{-2} \mathrm{mg} / \mathrm{L}$ & 152 & 142 & 192 & 175 & 158 & 152 & 197 & 180 \\
\hline Chloride $\mathrm{mg} / \mathrm{L}$ & 18 & 17 & 25 & 20 & 20 & 19 & 27 & 23 \\
\hline $\mathrm{N}-\mathrm{NO}_{2} \mu \mathrm{g} / \mathrm{L}$ & 0.8 & 0.3 & 0.45 & 0.52 & 0.52 & 0.45 & 0.75 & 0.58 \\
\hline $\mathrm{P}-\mathrm{PO}_{4} \mu \mathrm{g} / \mathrm{L}$ & 4.1 & 3.8 & 3.0 & 4.2 & 4.2 & 4.1 & 4.0 & 4.3 \\
\hline
\end{tabular}

Table 2. Physico-chemical variables that are recorded in Derbendikhan Lake during the study period.

\begin{tabular}{|c|c|c|c|c|c|c|c|c|}
\hline Sites & & Site & & & & Site & 2 & \\
\hline Variable sample date & 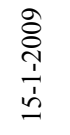 & 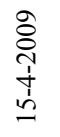 & $\begin{array}{l}\stackrel{8}{0} \\
\text { ஸे } \\
\stackrel{1}{n} \\
\text { n. }\end{array}$ & 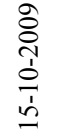 & $\begin{array}{l}\stackrel{8}{0} \\
\stackrel{1}{1} \\
\stackrel{1}{n}\end{array}$ & 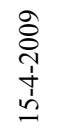 & 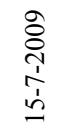 & 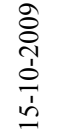 \\
\hline Air temp. ${ }^{\circ} \mathrm{C}$ & 13 & 21 & 34 & 25 & 12 & 21 & 35 & 24 \\
\hline Water temp. ${ }^{\circ} \mathrm{C}$ & 11 & 18 & 30 & 22 & 10 & 19 & 31 & 21 \\
\hline $\mathrm{pH}$ & 7.5 & 7.7 & 7.8 & 8.3 & 7.4 & 7.7 & 8.4 & 7.9 \\
\hline $\mathrm{EC} \mu \mathrm{s} / \mathrm{cm}$ & 400 & 420 & 460 & 480 & 382 & 418 & 470 & 448 \\
\hline TDS mg/L & 225 & 253 & 292 & 302 & 241 & 261 & 283 & 300 \\
\hline Alkalinity $\mathrm{mg} \mathrm{CaCO}_{3} / \mathrm{L}$ & 180 & 190 & 220 & 240 & 173 & 191 & 260 & 208 \\
\hline Hardness $\mathrm{mg} \mathrm{CaCO}_{3} / \mathrm{L}$ & 225 & 230 & 280 & 270 & 212 & 225 & 292 & 260 \\
\hline Dissolved Oxygen mg/L & 8.9 & 7.0 & 5.6 & 7.8 & 9.4 & 7.3 & 6.2 & 8.3 \\
\hline $\mathrm{Ca}^{+2} \mathrm{Mg} / \mathrm{L}$ & 60 & 54 & 74 & 62 & 55 & 48 & 65 & 60 \\
\hline $\mathrm{Mg}^{+2} \mathrm{mg} / \mathrm{L}$ & 19 & 18 & 23 & 21 & 18 & 19 & 21 & 20 \\
\hline $\mathrm{Na}^{+} \mathrm{mg} / \mathrm{L}$ & 9.3 & 9.7 & 11.2 & 9.8 & 8.8 & 9.2 & 10.6 & 8.4 \\
\hline $\mathrm{K}^{+1} \mathrm{mg} / \mathrm{L}$ & 1.8 & 3.0 & 4.9 & 2.0 & 1.5 & 3.3 & 4.5 & 1.8 \\
\hline$\left(\mathrm{SO}_{4}\right)^{-2} \mathrm{mg} / \mathrm{L}$ & 124 & 156 & 145 & 150 & 130 & 156 & 138 & 145 \\
\hline Chloride mg/L & 29 & 35 & 48 & 45 & 30 & 36 & 45 & 42 \\
\hline $\mathrm{N}-\mathrm{NO}_{2} \mu \mathrm{g} / \mathrm{L}$ & 0.55 & 0.60 & 0.38 & 0.45 & 0.45 & 0.55 & 0.29 & 0.48 \\
\hline $\mathrm{P}-\mathrm{PO}_{4} \mu \mathrm{g} / \mathrm{L}$ & 24.0 & 19.5 & 20.1 & 23.0 & 21.0 & 17.3 & 19.8 & 21.7 \\
\hline
\end{tabular}

Table 3. Physico-chemical variables that are recorded in Duhok Lake during the study period.

\begin{tabular}{|c|c|c|c|c|c|c|c|c|}
\hline Sites & & Sit & te 1 & & & & ite 2 & \\
\hline Variable sample date & $\begin{array}{l}\stackrel{8}{0} \\
\frac{i}{1} \\
\stackrel{1}{1}\end{array}$ & 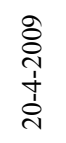 & $\begin{array}{l}\stackrel{8}{0} \\
\text { 1े } \\
\hat{i} \\
\text { ते }\end{array}$ & 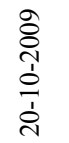 & $\begin{array}{l}\stackrel{8}{0} \\
\frac{1}{1} \\
\stackrel{1}{1}\end{array}$ & 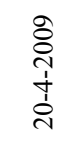 & $\begin{array}{l}\text { Oे } \\
\text { ते } \\
\hat{i} \\
\text { iे }\end{array}$ & 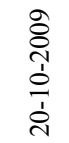 \\
\hline Air temp. ${ }^{\circ} \mathrm{C}$ & 9 & 17 & 27 & 20 & 8 & 16 & 28 & 18 \\
\hline Water temp. ${ }^{\circ} \mathrm{C}$ & 7 & 14 & 22 & 18 & 6 & 14 & 26 & 17 \\
\hline $\mathrm{pH}$ & 7.5 & 7.8 & 8.1 & 7.6 & 7.6 & 7.8 & 8.1 & 7.7 \\
\hline $\mathrm{EC} \mu \mathrm{s} / \mathrm{cm}$ & 1055 & 1110 & 1410 & 1338 & 1025 & 1120 & 1420 & 1352 \\
\hline TDS mg/L & 636 & 718 & 846 & 838 & 652 & 723 & 860 & 845 \\
\hline Alkalinity $\mathrm{mg} \mathrm{CaCO} / \mathrm{L}$ & 208 & 215 & 225 & 218 & 200 & 212 & 230 & 220 \\
\hline Hardness $\mathrm{mg} \mathrm{CaCO}_{3} / \mathrm{L}$ & 380 & 392 & 412 & 405 & 385 & 390 & 420 & 415 \\
\hline Dissolved Oxygen mg/L & 8.3 & 8.0 & 7.7 & 8.2 & 8.5 & 8.4 & 7.9 & 8.4 \\
\hline $\mathrm{Ca}^{+2} \mathrm{Mg} / \mathrm{L}$ & 88 & 86 & 102 & 95 & 86 & 85 & 104 & 96 \\
\hline $\mathrm{Mg}^{+2} \mathrm{mg} / \mathrm{L}$ & 34 & 32 & 37 & 34 & 35 & 31 & 38 & 37 \\
\hline $\mathrm{Na}^{+} \mathrm{mg} / \mathrm{L}$ & 16 & 17 & 19 & 17 & 17 & 18 & 20 & 18 \\
\hline $\mathrm{K}^{+1} \mathrm{mg} / \mathrm{L}$ & 4.2 & 4.6 & 5.0 & 4.9 & 4.0 & 4.8 & 5.0 & 4.8 \\
\hline$\left(\mathrm{SO}_{4}\right)^{-2} \mathrm{mg} / \mathrm{L}$ & 406 & 405 & 418 & 435 & 400 & 405 & 420 & 438 \\
\hline Chloride $\mathrm{mg} / \mathrm{L}$ & 63 & 60 & 68 & 66 & 54 & 50 & 72 & 65 \\
\hline $\mathrm{N}-\mathrm{NO}_{2} \mu \mathrm{g} / \mathrm{L}$ & 0.30 & 0.32 & 0.31 & 0.26 & 0.32 & 0.30 & 0.20 & 0.26 \\
\hline $\mathrm{P}^{-\mathrm{PO}_{4}} \mu \mathrm{g} / \mathrm{L}$ & 15.1 & 14.8 & 14.0 & 14.6 & 15.3 & 14.3 & 13.7 & 14.2 \\
\hline
\end{tabular}

Table 4. Mean values recorded in Dokan \& Derbendikhan \& Duhok Lake during the study period.

\begin{tabular}{|c|c|c|c|c|c|c|}
\hline \multirow{2}{*}{$\begin{array}{c}\text { Lakes } \\
\text { Sites }\end{array}$} & \multicolumn{2}{|c|}{ Dokan } & \multicolumn{2}{|c|}{ Derbendikhan } & \multicolumn{2}{|c|}{ Duhok } \\
\hline & 1 & 2 & 1 & 2 & 1 & 2 \\
\hline Variable sample date & $\sum^{\mathbb{E}}=$ & $\sum_{\Sigma}^{\Phi}=$ & $\sum^{\mathbb{E}}=$ & $\sum^{\mathbb{E}}=$ & $\sum^{\mathbb{Z}}=$ & $\sum_{\Sigma}^{\mathbb{E}}=$ \\
\hline Air temp. ${ }^{\circ} \mathrm{C}$ & 22 & 21.3 & 23.3 & 23 & 18.3 & 17.5 \\
\hline Water temp. ${ }^{\circ} \mathrm{C}$ & 19 & 19.5 & 20.3 & 20.3 & 15.3 & 15.8 \\
\hline $\mathrm{pH}$ & 7.7 & 7.6 & 7.8 & 7.9 & 7.8 & 7.8 \\
\hline $\mathrm{EC} \mu \mathrm{s} / \mathrm{cm}$ & 310 & 326.3 & 440 & 430 & 1229 & 1235 \\
\hline TDS mg/L & 192.3 & 204.8 & 268 & 271.3 & 780 & 770 \\
\hline Alkalinity $\mathrm{mg} \mathrm{CaCO}_{3} / \mathrm{L}$ & 206 & 210 & 208 & 208 & 224 & 215 \\
\hline Hardness $\mathrm{mg} \mathrm{CaCO}_{3} / \mathrm{L}$ & 165 & 177 & 251 & 247.3 & 401 & 408 \\
\hline Dissolved Oxygen mg/L & 6.6 & 6.4 & 7.4 & 7.8 & 8.4 & 8.2 \\
\hline $\mathrm{Ca}^{+2} \mathrm{Mg} / \mathrm{L}$ & 40.5 & 45.5 & 62.5 & 57 & 94 & 94.8 \\
\hline $\mathrm{Mg}^{+2} \mathrm{mg} / \mathrm{L}$ & 15.8 & 17 & 20.3 & 20 & 34 & 35.3 \\
\hline $\mathrm{Na}^{+} \mathrm{mg} / \mathrm{L}$ & 4.5 & 5.7 & 10 & 9.3 & 17.5 & 18.3 \\
\hline $\mathrm{K}^{+1} \mathrm{mg} / \mathrm{L}$ & 1.5 & 1.7 & 2.9 & 2.8 & 4.7 & 4.5 \\
\hline$\left(\mathrm{SO}_{4}\right)^{-2} \mathrm{mg} / \mathrm{L}$ & 165 & 171.8 & 143.8 & 142.3 & 410 & 419.5 \\
\hline Chloride mg/L & 20 & 22.3 & 39.3 & 38.3 & 64 & 60.3 \\
\hline $\mathrm{N}-\mathrm{NO}_{2} \mu \mathrm{g} / \mathrm{L}$ & 0.52 & 0.58 & 0.49 & 0.45 & 0.29 & 0.29 \\
\hline $\mathrm{P}_{-} \mathrm{PO}_{4} \mu \mathrm{g} / \mathrm{L}$ & 3.8 & 4.15 & 21.7 & 20 & 14.6 & 14.4 \\
\hline
\end{tabular}


of Iraqi inland waters [15]. Similar conclusions are made by $[13,23,24]$.

EC values in this survey range between $(205-1420 \mu \mathrm{S} /$ $\mathrm{cm}$ ) in Dokan and Duhok reservoirs respectively which are slightly higher than the permissible level recommended by the WHO for drinking water [26]. Several factors influence the conductivity including temperature, ionic mobility and ionic valences. In turn, conductivity provides a rapid mean of obtaining approximate knowledge of total dissolved solids concentration and salinity of water sample [21]. Similar conclusions are made by $[13,23,24]$.

Moreover, the total dissolved solids values are found in the same trend of the EC. However; the higher value of TDS recorded during summer is $860 \mathrm{mg} / \mathrm{L}$ whereas the lower value is $132 \mathrm{mg} / \mathrm{L}$ in Duhok and Dokan Lake respectively. These variations may be due to the size of the water body, inflow of water, consumption of salt by algae and other aquatic plants, dilution and the rate of evaporation [26]. Similar conclusions are made by $[13,23$, 24].

In this study, Derbendikhan lake shows a minimum alkalinity value of $173 \mathrm{mg} \mathrm{CaCO} / \mathrm{L}$ while Dokan lake shows a maximum alkalinity value of $250 \mathrm{mg} \mathrm{CaCO} / \mathrm{L}$. [27] reports that pollution by sewage and its decomposition seems to be a possible cause of the higher value of alkalinity in the water. This variation among lakes due to the increase in bicarbonate concentrations during hot seasons may be attributed to the fact that the increase in temperature accelerates the organic matter accessible to bacterial decomposition, where the $\mathrm{HCO}^{-3}$ is the final product of this decomposition [28]. Fluctuations in total alkalinity and total hardness are similar but the amount of the total hardness is significantly greater than that of the total alkalinity. Similar conclusions are also made by $[13,23,24]$.

During the period of study, the total hardness of Dokan, Derbendikhan and Duhok lakes has varied from 145 to $420 \mathrm{mg} \mathrm{CaCO}_{3} / \mathrm{L}$ in Duhok and Dokan Lake respectively. The results obtained by water surveys, conducted in this investigation, have showed that total hardness values are often higher than the minimal permissible level recommended by the WHO for drinking water [26]. The hardness and alkalinity of the lake are affected by the type of minerals in the soil and watershed bedrock, and also by the amount of lake water coming into contact with these minerals. If a lake gets groundwater from aquifers containing limestone minerals such as calcite $\left(\mathrm{CaCO}_{3}\right)$ and dolomite $\left(\mathrm{CaMgCO}_{3}\right)$, hardness and alkalinity will be high [28].

Dissolved oxygen is found to be a maximum of 9.5 $\mathrm{mg} / \mathrm{L}$ in Dokan Lake and a minimum of $5.0 \mathrm{mg} / \mathrm{L}$ recorded in Dokan Lake too. Its concentrations are above 5 $\mathrm{mg} / \mathrm{L}$, which is adequate enough to support aquatic life.
The increase in dissolved oxygen levels might be the result of runoffs accounted for by winter rains [29]. The dissolved oxygen shows maximum values in winter. This may be due to temperature variations. Dissolved oxygen thus shows inverse relationship with water temperature [30].

Calcium is one of the most abundant ions of the natural waters. The highest recorded value is $104 \mathrm{mg} / \mathrm{l}$ at locality 2 during summer in Duhok Lake and the lowest is $30.0 \mathrm{mg} / 1$ in locality 1 during spring in Dokan Lake.

Magnesium concentration in water always remains lower than that of calcium content. The highest recorded value is $38.8 \mathrm{mg} / \mathrm{l}$ in site 2 during summer in Duhok Lake while the lowest is $12.0 \mathrm{mg} / \mathrm{l}$ in site 1 during spring in Dokan Lake. The variation in calcium and magnesium concentrations may be related to the geology of the area, climate and seasonal variations, different biogeochemical activities in the water ecosystem, human activities, water uses and due to the addition of surface run-off from agricultural and other catchment area [31]. Similar conclusions are made by $[13,23,24]$.

Water samples show that the concentration of sodium ion range from the minimum value of $3.5 \mathrm{mg} / \mathrm{L}$ measured in Dokan Lake and the maximum value of $20.0 \mathrm{mg} / \mathrm{L}$ measured in Duhok.

Regarding the present investigation, water samples from studied sites show concentration of potassium which ranges from $1.0 \mathrm{mg} / \mathrm{L}$ recorded in Dokan Lake to $5.0 \mathrm{mg} / \mathrm{L}$ in Duhok Lake, while the maximum value of potassium in Derbendikhan Lake is $4.9 \mathrm{mg} / \mathrm{L}$. These variations of sodium and potassium among these Lakes may be due to the Seasonal changes, climate, biological activity, geology of the area in addition to the anthropogenic inputs to the water body [32]. The obtained results agree with the results of $[13,23,24]$, all the studied water samples reveal lower concentration of potassium than sodium. Both sodium and potassium show similarity in the timing of increase and decrease, this comes in accordance with the observations of $[13,23,24]$.

Concerning the Sulfate contents of lake water, they indicate variations within 124 - $438 \mathrm{mg} / \mathrm{L}$. Sulfate concentrations show great differences through the seasons and indicate high values in autumn. This may be because of the little dilution in a dry season and these variations among these lakes may be due to the fact that the sulfate in lake water is primarily related to the types of minerals found in the watershed and acid rain. Industries and utilities that burn coal release sulphur compounds into the atmosphere that are in turn carried into lakes by rainfall [28].

Chloride fluctuates between $72 \mathrm{mg} / \mathrm{L}$ and $17 \mathrm{mg} / \mathrm{L}$. Seasonally, chloride is found high in summer and low during winter. Higher chloride values are recorded in this study during summer with no definite pattern of fluctua- 
tions. The chloride concentration of lake water depends upon the degree of pollution resulting from the waste materials poured into the lakes. The presence of chloride $\left(\mathrm{Cl}^{-}\right)$, where it does not occur naturally, indicates possible water pollution [33]. Similar observation is detected by $[13,23,24]$.

Concentration of nitrite fluctuates between $0.20-0.80$ $\mu \mathrm{g} \mathrm{N}-\mathrm{NO}_{2} / \mathrm{L}$ in Duhok and Dokan Lake respectively. These variations in the study area are mainly due to the atmosphere, surface runoff, sewage discharges, agricultural fertilizers and organic wastes [34]. The highest recorded values may be due to the increased phytoplankton excretion, oxidation of ammonia and the reduction of nitrate and also by the recycling of nitrogen and bacterial decomposition of planktonic detritus which are present in the environment [35]. Further, the denitrification and airsea interaction exchange of chemicals are also responsible for these increased values [36]. On the other hand, the low value recoded during summer season may be due to less freshwater inflow and high salinity [37].

Higher concentration of inorganic phosphates $(24 \mu \mathrm{g}$ P-PO4/L) observed during winter season in Derbendikhan Lake can also be related to the weathering of rocks soluble alkali metal phosphates. The addition of super phosphates applied in the agricultural fields as fertilizers and alkyl phosphates used in households as detergents can be regarded as additional sources of inorganic phosphates during the season. The low phosphates value (3 $\mu \mathrm{g}$ P-PO4/L) recorded during summer in Dokan Lake could be attributed to the limited flow of freshwater, high salinity and utilization of phosphate by phytoplankton $[38,39]$. These variations may be due to the various processes like adsorption and desorption of phosphates and buffering action of sediment under different environmental conditions [39].

During the last decade, Dokan, Derbendikhan and Duhok Lakes have been subject to rapid decline in water characteristics status which is possibly due to the increase in the population and human activities.

\section{CONCLUSIONS}

From the above discussion one can conclude the following observations:

1) The highest degrees of Air and water temperatures are recorded in Derbendikhan Lake, while the lowest degrees are recorded in Duhok Lake;

2) The Maximum value of total dissolved solids is calculated in Duhok Lake, while the minimum value is calculated in Dokan Lake;

3) The $\mathrm{pH}$ in the studied area is always on alkaline side of neutrality;

4) According to hardness, Duhok and Derbendikhan Lakes are considered very hard water, while Dokan Lake is considered hard water;
5) The minimum value of dissolved oxygen in the study area is never less than $5 \mathrm{mg} / \mathrm{L}$ which is recorded in Dokan Lake;

6) With regard to nutrient enrichment status, Dokan, Derbendikhan and Duhok Lakes can be considered Mesotrophic Lakes.

\section{REFERENCES}

[1] Mullar, R.M., Rajashekhar, M., Vijaykumar, K. and Haliked, N.S. (2010) Seasonal variation in physico-chemical parameters of Hirahalla Reservoir, Koppal District Karnataka. International Journal of Systems Biology, 2, 1620.

[2] Adorn, A.D. (1985) Work book on limnology. Pratibha Pub., Bangalore.

[3] Carpenter, S.R., Caraco, N.F. and Correll, D.L. (1998) Nonpoint pollution of surface waters with phosphorus and nitrogen. Ecological Applications, 8, 559-568. doi:10.1890/1051-0761(1998)008[0559:NPOSWW]2.0.C $\underline{\mathrm{O} ; 2}$

[4] Simeonov, V., Stratis, J.A., Samara, C., Zachariadis, G., et al. (2003) Assessment of the surface water quality in Northern Greece. Water Research, 37, 4119-4124. doi:10.1016/S0043-1354(03)00398-1

[5] Sugnan, V.V. (1995) Reservoir fisheries of India. Fisheries Technical Papers No. 345, Food and Agriculture Organization of the United Nations (FAO), Rome.

[6] Muley, D.V. and Gaikwad, P.T. (1999) Limnological studies of Shiroli reservoir-A case study. In: Kumar, K.V., Ed., Freshwater Ecosystem of India, Daya Publishing House, Delhi, 109-132.

[7] Chatawal, G.R. (1998) Encyclopedia of environmental biology, Vol. 2. Anmol Publications Pvt. Ltd., New Delhi, 287-301.

[8] Boyd, C.E. and Tucker, C.S. (1998) Pond aquaculture and water quality management. Kluwer Academic Pub., London, 44-48. doi:10.1007/978-1-4615-5407-3

[9] Rahi, K.A. and Halihan, T. (2010) Changes in the salinity of the Euphrates River System in Iraq. Regional Environment Change, 10, 27-35. doi:10.1007/s10113-009-0083-y

[10] Jones, C., Sultan, M., Yan, E., Milewski, A., Hussein, M., Al-Dousari, A., Al-Kaisy, S. and Becker, R. (2008) Hydrologic impacts of engineering projects on the TigrisEuphrates System and its Marshlands. Journal of $\mathrm{Hy}$ drology, 353, 59-75. doi:10.1016/j.jhydrol.2008.01.029

[11] APHA. (1998) Standard methods for the examination of water and wastewater. 20th Edition, American Public Health Association, Washington DC.

[12] Shaban, A.A.G. (1980) An ecological study on phytoplankton in Dokan Lake. M.Sc. Thesis, Sulaimamiyah University, Sulaimaniyah.

[13] Toma, J.J. (2000). Limnological study of Dokan Lake, Kurdistan region of Iraq. M.Sc. Thesis, University of Salahaddin, Arbil.

[14] Bunic, D. (1955) Dokan Dam Project. Ministry of Irriga- 
tion, Government of Iraq.

[15] Rozoska, J. (1980) Euphrates and Tigris, Mesopotamia ecology and destiny, Vol38. In: Junk, W., Ed., Monographiae Biologica, The Hague-Boston, London. doi:10.1007/978-94-009-9171-2

[16] Al-Shalash, A.H. (1966) The climate of Iraq. The Cooperative printing, Presses Workers Society, Amman.

[17] Anon (2006) The World Bank, Dokan and Derbendikhan Emergency Hydropower. Consultancy Services for Dokan and Derbendikhan Dam Inspections, Inspection report (final), E1537.SMEC. Section A: Complementary Grouting in Dam Main Remedial Works (Phase1), Analysis of Dam Behavior, Review of Previous Reports Recommendations, Coyne at Bellier, 1975.

[18] Szczerbowski, J.A., Bartel, R. and Ciepielewski, W. (2001) Hydrological characteristics of Dokan and Derbendikhan Dam and lakes of Tharthar, Habbaniya and Razzazah. Polish Fisheries, 9, 7-18.

[19] Guest, E. (1966). Flora of Iraq, Vol 1. Ministry of Agriculture, Baghdad.

[20] Al-Ganabi, H.A. (1985) Duhok city: A study in urban geography. University of Mosul, Mosul.

[21] Odum, E.P. (1971) Fundamentals of ecology. W.B. Saunders Company, Philadelphia.

[22] Mahmoud, S.A. (2002) Evaluation of toxicity of some pollutant on histological and biochemical features of Orcachomis niloticus in River Nile. Ph.D. Thesis, Zagazig University, Zagazig.

[23] Rasheed, R.O. (2008) Evaluation of heavy metals and polyaromatic hydrocarbons in water, fish, and sediments within Derbendikhan reservoir. Ph.D. Thesis, University of Sulaymaniyah, Sulaymaniyah.

[24] Raoof, I.Y. (2002) A phycolimnological study on Duhok impoundment and its main Watershade. Ph.D. Thesis, University of Dohuk, Dohuk.

[25] Ahipathy, M.V. and Puttaiah, E.T. (2006) Ecological Characteristics of Vrishabhavathy River in Bangalore (India). Environmental Geology, 49, 1217-1222. doi:10.1007/s00254-005-0166-0

[26] World Health Organization (WHO) (2004) Guidelines for drinking-water quality. 3rd Edition, World Health Organization (WHO), Geneva.

[27] Abdo, M.H. (2005) Physico-chemical characteristics of Abu Za'baal Ponds, Egypt. Egyptian Journal of Aquatic Research, 31, 1-15.
[28] Yalçın, T., Aysun, T., Ekrem, M. and Alpaslan, A. (2005) Some physicochemical characteristics of Yarseli Lake, Hatay, Turkey. Turkish Journal of Fisheries and Aquatic Sciences, 5, 35-42.

[29] Tepe, Y. and Mutlu, E. (2004). Physico-chemical characteristics of Hatay Harbiye spring water. Journal of the Institute of Science and Technology of Dumlupınar University, 6, 77-88.

[30] Ali, S.S. (1999) Freshwater fishery biology. Naseem Book Depot, Hyderabad, 108-114.

[31] Kumar, A., Qureshi, T.A., Parashar, A. and Patiyal, R.S. (2006) Seasonal variation in physico-chemical characteristics of Ranjit Sagar reservoir, Jammu \& Kashmir. Journal of Ecophysiology \& Occupational Health, 6, 159-163.

[32] Quinby-Hunt, M.S., McLaaughlin, R.D. and Quintanila, A.T. (1986) Instrumentation for Environmental Monitoring. Volume 2: Water. 2nd Edition, Wiley-Interscience, New York.

[33] Swarup, K. and Singh, S.R. (1976) Limnological studies on Suraha Lake. Journal of the Inland Fisheries Society of India, 11, 22-23.

[34] American Public Health Association, American Water Works Association and World Environment Federation (2005) Standard methods for examination of water and wastewater. 21st Edition, American Public Health Association, Washington DC.

[35] Govindasamy, C., Kannan, L. and Azariah, J. (2000) Seasonal variation in physico-chemical properties and primary production in the coastal water biotopes of Coromandel Coast, India. Journal of Environmental Biology, 21, 1-7.

[36] Mathew, L. and Pillai, V.N. (1989) Chemical characteristics of the waters around Andaman during late winter. Proceedings of the 1st Workshop on Scientific Results of FORV Sagar Sampada, Kochi, 5-7 June 1989, 15-18.

[37] Murugan, A. and Ayyakkannu, K. (1991) Ecology of Uppanar backwater, Cuddalore: I. Physico-chemical parameters. Mahasagar-Bulletin of National Institute of Oceanography, 24, 31-38.

[38] Rajasegar, M. (2003) Physico-chemical characteristics of the Vellar estuary in relation to shrimp farming. Journal of Environmental Biology, 24, 95-101.

[39] Tiwari, L.R. and Nair, R.V. (1993) Zooplankton composition in Dharamtar creek adjoining Bombay harbour. Indian Journal of Marine Sciences, 22, 63-69. 